\title{
Overborgmester Sievers' fald 1936
}

\section{Af Carsten Mogensen}

Den flensborgske overborgmester dr. Sievers pludselige afskedigelse i 1936 vakte stor opsigt i samtiden på grund af den fremtrædende rolle, Sievers havde spillet $i$ den nazistiske grænsepolitik. I denne artikel analyseres årsagerne til Sievers' fald, og forfatteren konkluderer, at personlige uoverensstemmelser mellem de slesvig-holstenske nazister og ikke udenrigspolitiske hensyn var hovedărsagen til afskedigelsen.

\section{Indledning}

Da Flensborgs nazistiske overborgmester dr. Wilhelm Sievers i slutningen af januar 1936 blev afskediget på gråt papir af det tyske indenrigsministerium under henvisning til en lov, udstedt med henblik på udrensning af nazismens modstandere i det tyske forvaltningsapparat, blev denne begivenhed livligt kommenteret i den danske presse. Dr. Sievers var en af den slesvig-holstenske nazismes få kompetente, professionelle kommunalpolitikere, formand for den vigtigste slesvigholstenske grænsepolitiske organisation Schleswig-Holsteiner-Bund (SHB) og havde i 1933 gjort sig bekendt som leder af de slesvigholstenske nazisters forsøg på at udnytte den nationalistiske stemning i Tyskland til et angreb på den dansk-tyske grænse af 1920 . Sievers havde desuden fungeret som ledende kraft $\mathrm{i}$ den rigstyske nazismes forsøg på at nazificere det tyske mindretal i Nordslesvig og ensrette dette under det rigstyske NSDAP's ledelse. Det var derfor forståeligt, at den danske og især den sønderjyske presse ivrigt gisnede om årsagerne til, at netop denne mand pludselig var faldet $\mathrm{i}$ unåde.

Når Sievers' afskedigelse vakte en sådan interesse i Danmark, skyldtes det først og fremmest muligheden for, at der kunne vare tale 
om en udenrigspolitisk tilkendegivelse, en gestus over for Danmark. Hverken Weimar-republikken eller Hitler-regimet havde vist tilbøjelighed til at anerkende grænsen af 1920, og det kan derfor ikke undre, at fjernelsen af en af dens voldsomste kritikere fra grænseområdet kunne blive og blev fortolket som et tegn på, at den nazistiske regering onskede at slå ind på en ny mildere kurs i forholdet til Danmark. Karakteristisk var det imidlertid, at der netop var tale om gisninger. Nogen klar viden om, hvad der egentlig var gået forud for denne opsigtsvakkende afskedigelse, var den danske presse, endsige den danske regering ikke $i$ besiddelse af, og var den ensrettede tyske presse bedre informeret, havde den ingen mulighed for at delagtiggøre offentligheden i sin viden. Det spørgsmål, som her skal analyseres, er, om der virkelig var hold i danske spekulationer om et tysk kursskifte, eller om der var andre, og i så fald hvilke, årsager til den pludselige afskedigelse af overborgmesteren.

På grundlag af hidtil stort set utilgxngelige kilder, således Sievers' personalakter fra Document Center i Berlin, hans egne erindringer fra overborgmestertiden i Flensborg og et mindeskrift udgivet af hans søn professor Kai Detlev Sievers, samt materiale fra to allerede offentliggjorte fremstillinger om forholdet mellem Tyskland og det tyske mindretal i Nordslesvig i 1930'erne, skal her forsøges at rekonstruere det hændelsesforløb, som gik forud for afskedigelsen af Sievers, og at tage stilling til, hvad årsagen var til, at det gik, som det gik. Først skal dog kort skildres Sievers' baggrund og karriere, hans politiske virksomhed og hans personlige rolle $\mathrm{i}$ den dansk-tyske grænsestrid.

\section{Sievers' virksombed for 1936}

Wilhelm Sievers blev født den 2. dec. 1896 i Kiel som søn af rangermester ved rigsbanerne Detlef Asmus Sievers og Elsabe Margaretha Magdalena, født Schell. På fædrene side nedstammede han fra en holstensk bonde- og håndværkerslægt, på mødrene side fra slesvigske bønder. Selv om faderen var statstjenestemand, var familien på ingen måde velhavende; men sønnen Wilhelm kom ikke desto mindre først i mellemskole, siden i gymnasiet, et skoleforløb, som i betragtning af familiens sociale placering må betegnes som bemærkelsesværdigt $\mathrm{i}$ datidens Tyskland. Ved krigsudbruddet $\mathrm{i}$ august 1914 meldte han sig 
i en alder af 17 år som frivillig og overflyttedes i midten af december 1914 til aktiv fronttjeneste. Efter slaget ved Somme i 1916 blev han i oktober samme år af kejseren personligt dekoreret med jernkorset af 1. klasse. Efter lengere tids sygdom overgik han i april 1917 til reserven, og da han endnu ikke var fyldt 21 år, ansøgte hans forældre i september 1917 om at få ham overført til etapetjeneste. I december 1917 havde han imidlertid nået myndighedsalderen og meldte sig $\mathrm{i}$ foråret 1918 påny mod forældrenes vilje til fronttjeneste. Indtil krigens slutning $i$ november samme år fungerede Sievers som kompagnifører respektive bataillonsadjudant. Den 13. jan. 1919 udtrådte han endeligt af hæren. I orlovsperioderne havde han forberedt sig til studentereksamen, som han tog i $1917 . .^{1}$

Som så mange andre unge officerer var han frustreret over det tyske nederlag og de hårde fredsbetingelser. Den socialistiske revolution så han dog, som det var naturligt med hans baggrund, ikke som løsningen på Tysklands problemer. I foråret 1919 deltog han aktivt $\mathrm{i}$ nedkæmpelsen af Spartakistopstanden i Kiel, og fra den 23. april 1919 til den 15. september samme år var han medlem af Frikorps Löwenfeld, III. Marinebrigade. ${ }^{2}$ I sommersemestret 1919 påbegyndte han sine studier ved universitetet i Marburg med fagene germansk og romansk filologi. Efter få ugers forløb besluttede han dog i stedet at læse jura.s Andet semester tilbragte han i Königsberg og deltog her som medlem af en officersstodtrop aktivt i Kapp-kuppet.4 I juni 1922 bestod han $\mathrm{i}$ Kiel sin referendar-eksamen; men på grund af økonomiske vanskeligheder så han sig nødsaget til at opgive at afslutte sin praktikanttjeneste (Vorbereitungsdienst: praktisk uddannelse for embedsmænd) i retsvæsnet og overtog i stedet en stilling som Syndikus, d.v.s. juridisk rådgiver, for det tyske landbrugs centralorganisation Reichslandbund i kreds Bremervörde i Niedersachsen. ${ }^{5}$

Straks efter grundlæggelsen af det såkaldte Deutschvölkische Schutz und Trutz-Bund, en altysk og antisemitisk højreekstremistisk organisation, som blev oplost efter mordet på udenrigsminister Rathenau i 1922, havde Sievers indmeldt sig i dette. Efter organisationens opløsning $\mathrm{i}$ sommeren 1922 indtrådte han $\mathrm{i}$ nazistpartiet. Da dette efter Hitlers losladelse fra Landsberg i 1925 blev gendannet, indmeldte han sig påny $\mathrm{i}$ NSDAP og fik medlemsnummer 12.007. I de følgende år var han først Ortsgruppenleiter, siden Kreisleiter i Bremervörde, indtil han den 31 . dec. 1927 nedlagde denne post. ${ }^{6}$ 
Allerede i sommeren 1927 var han blevet afskediget fra sin stilling i Reichslandbund på grund af sin politiske virksomhed for NSDAP, der bragte ham i modsætning til den overvejende tysk-nationale eller welfiske (d.v.s. hannoveranske separatister) ledelse af Reichslandbunds afdeling i Bremervörde. Forsøg på at få en ny stilling ved partiets hjxlp mislykkede; derimod erhvervede han i februar 1928 den juridiske doktorgrad for afhandlingen Die Zwangsvollstreckung in das bewegliche Vermögen bei Untereigentum. Kort forinden var han blevet valgt til borgmester $\mathrm{i}$ flækken Visselhövede på Lüneburger Heide. $^{7}$

Stillingen som politisk embedsmand reducerede hans muligheder for aktiv deltagelse $\mathrm{i}$ det politiske liv; men Sievers fungerede dog som skolingsleder $\mathrm{i}$ kommunalpolitik og som leverandør af artikler (under pseudonymet Eike v. Repkow) til de nazistiske blade Niedersachsenstürmer og Schleswig-Holsteinische Tageszeitung. I februar 1931 lykkedes det ham at blive valgt til borgmester $i$ den sydslesvigske købstad Eckernförde. Samtidig virkede han imidlertid fortsat som propagandist for NSDAP, og da han i Altona, Wandsbek og Harburg havde optrådt som taler for dette parti, indledte regeringspræsidenten i Slesvig en tjenstlig undersøgelse af hans adfærd, som dog lob ud i sandet. Fra 1930-1933 fungerede han tillige som medarbejder ved Mitteilungsblätter für NS-Gemeindevertreter, d.v.s. en slags informationsblade for nazistiske kommunalbestyrelsesmedlemmer, samtidig med at han var partiets Gauamtsleiter für Kommunalpolitik i Slesvig-Holsten. ${ }^{8}$ I marts 1933 blev han indvalgt i provinslanddagen $\mathrm{i}$ Kiel for NSDAP og var medlem af dennes forretningsudvalg, provinsialudvalget, indtil dettes opløsning. ${ }^{9}$ Sievers tilhørte altså, hvad man kan kalde den hårde kerne $\mathrm{i}$ det slesvig-holstenske nazistparti.

Efter valgsejren ved rigsdagsvalget den 31 . juli 1932, hvor nazisterne var blevet provinsen Slesvig-Holstens største parti med $51 \%$ af stemmerne, var de nazistiske ledere begyndt at interessere sig for de grænsepolitiske organisationer i Slesvig-Holsten. Som største parti i provinsen krævede de formandsposten i SHB. Den nazistiske kandidat var Sievers, som fra marts 1932 havde været formand for SHB's Eckernförde-afdeling. Forsøget mislykkedes imidlertid, og den slesvig-holstenske Gauleiter Hinrich Lohse proklamerede derefter, at NSDAP havde tabt interessen for SHB og i stedet ville oprette sin 
egen organisation. Lohse lod oprette en grænsepolitisk afdeling under ledelse af pastor Johann Peperkorn fra Fjolde i Sydslesvig; men på grund af den indre udvikling i SHB, hvor formanden i december 1932 efter kraftig indre kritik frivilligt nedlagde sin post, blev denne grænsepolitiske afdeling aldrig udbygget til en egentlig konkurrent til SHB. I stedet blev Sievers den 12. feb. 1933, altså efter Hitlers udnævnelse til rigskansler, valgt til formand for $\mathrm{SHB}$ uden modkandidat. Af de 128 stemmeberettigede var 103 tilstede. 72 stemte på Sievers; 31 stemmesedler var blanke. ${ }^{10}$

Selv om Sievers var det eneste partimedlem i SHB-bestyrelsen, ${ }^{11}$ betød hans valg alligevel, at nazisterne nu havde overtaget kontrollen med SHB's politiske linie. Den ny ledelses proklamerede mål var at gøre »uretten fra 1920 " god igen og med alle midler at indprente den slesvig-holstenske befolkning pligten til at genvinde Nordslesvig. ${ }^{12}$ Sidst i februar 1933 rejstes på et offentligt made i Flensborg, hvor b. a. Peperkorn talte, grænserevisionskravet åbenlyst, og den 24 . marts 1933 holdt Sievers i Slesvig en tale, hvori han bl. a. sagde følgende: »Vi vil ikke længere tåle danskernes uret fra 1918 til 1920. $\mathrm{Vi}$ vil aldrig anerkende denne grænse. $\mathrm{Vi}$ vil sørge for, at denne grænse bliver revideret, og vel at mærke således, som vi bestemmer $\operatorname{det} \ldots{ }^{13}{ }^{13}$

Sådanne udtalelser, som under vekslende former blev gentaget af de ledende slesvig-holstenske nazister og fulgt op af den tyske grænsepresse i de kommende uger, vakte voldsom uro i Danmark, og heller ikke udelt tilfredshed $\mathrm{i}$ Berlin eller hos mindretalsledelsen i Nordslesvig. Kampagnen blev afblæst efter ordre fra Berlin; men $i$ hvert fald et af formålene var nået, nemlig at vække de tysksindede nordslesvigeres interesse og sympati for nazismen. ${ }^{14}$ Vxgten af den rigstyske afstandtagen fra SHB's og de slesvig-holstenske nazisters private udenrigspolitik reduceredes dog noget, da Sievers den 12. maj 1933 blev udnævnt til kommissarisk (d.v.s. provisorisk) landråd i Flensborg landkreds, altså umiddelbart op ad grænsen, hvilket vakte lige så stor opmærksomhed i Danmark som tilfredshed i SlesvigHolsten. ${ }^{15}$

På dette tidspunkt havde grænsekampagnen imidlertid allerede kulmineret. Sievers og hans medkæmpere havde modtaget klare instrukser fra Berlin om at ophøre med ophidsende taler, og en stort anlagt "Grænselandstilkendegivelse« $\mathrm{i}$ Rendsborg den 18. juni blev 
derfor noget af en antiklimaks. Konklusionen på Sievers' tale ved denne lejlighed, som var godkendt af såvel det tyske udenrigsministerium som NSDAP's udenrigspolitiske kontor og propagandaministeriet, var, at selv om man ganske vist ikke havde skiftet mening om grænsen i Slesvig-Holsten, så måtte man indordne sig under de store linier i den tyske udenrigspolitik, som på dette tidspunkt ikke tilsigtede nogen konfrontation med de skandinaviske lande. ${ }^{16}$

Grænsekampagnens afblxsning var ikke ensbetydende med, at Sievers var faldet $\mathrm{i}$ unåde. Den 23. juni 1933 udnævinte lederen af Verein für das Deutschtum im Ausland, VDA, Tysklands største grænsepolitiske organisation, dr. Sievers til landsfører for VDA i Slesvig-Holsten, og den 12. juli blev SHB og VDA's slesvig-holstenske sektion släet sammen til én organisation under Sievers' ledelse. ${ }^{17}$ Den 29. juni havde Flensborg landkreds' kredsdag, d.v.s. amtsråd, énstemmigt opfordret indenrigsministeriet til at fastansæette Sievers som landråd; men i stedet blev han den 24. sept. 1933 valgt til overborgmester i Flensborg, ifølge ham selv ikke efter eget ønske. ${ }^{18}$ I begyndelsen af juni havde de flensborgske nazister, for hvilke Sievers var kommissarisk Kreisleiter, egenmægtigt afsat overborgmester v. Hansemann og forjaget ham fra byen. ${ }^{19}$ Sievers hxvder intet at have haft med denne affære at gøre, ${ }^{20}$ og det er da muligt, at han ikke var initiativtageren hertil. Det er imidlertid givet, at en sådan aktion ikke ville have kunnet gennemføres mod Kreisleiter'ens vilje, og det var da også en udbredt opfattelse i Flensborg, at Sievers var manden bag v. Hansemanns fald.

Sievers hævder selv at have haft et udmærket forhold til v. Hansemann og kun at have søgt overborgmesterposten på Gauleiter Lohses udtrykkelige forlangende. ${ }^{21}$ Byens financielle situation var i 1933 fortvivlet, og det forekommer derfor naturligt, hvis Lohse ønskede at besætte overborgmesterstillingen netop $i$ denne by med en erfaren embedsmand. Som professionel forvaltningsembedsmand og "Alter Kämpfer« var Sievers et oplagt emne til en høj post. Der er da heller intet, der tyder på, at Sievers ikke levede op til de forventninger, som man stillede til ham. I hans embedsperiode lykkedes det bl. a. at bringe orden $\mathrm{i}$ byens finanser, at nedbringe arbejdslosheden vxsentligt, at sæette gang $\mathrm{i}$ erhvervslivet, at tilvejebringe et rimeligt forhold til det danske mindretal i byen og sidst, men ikke mindst, at bringe bystyret nogenlunde helskindet igennem den nazistiske ens- 


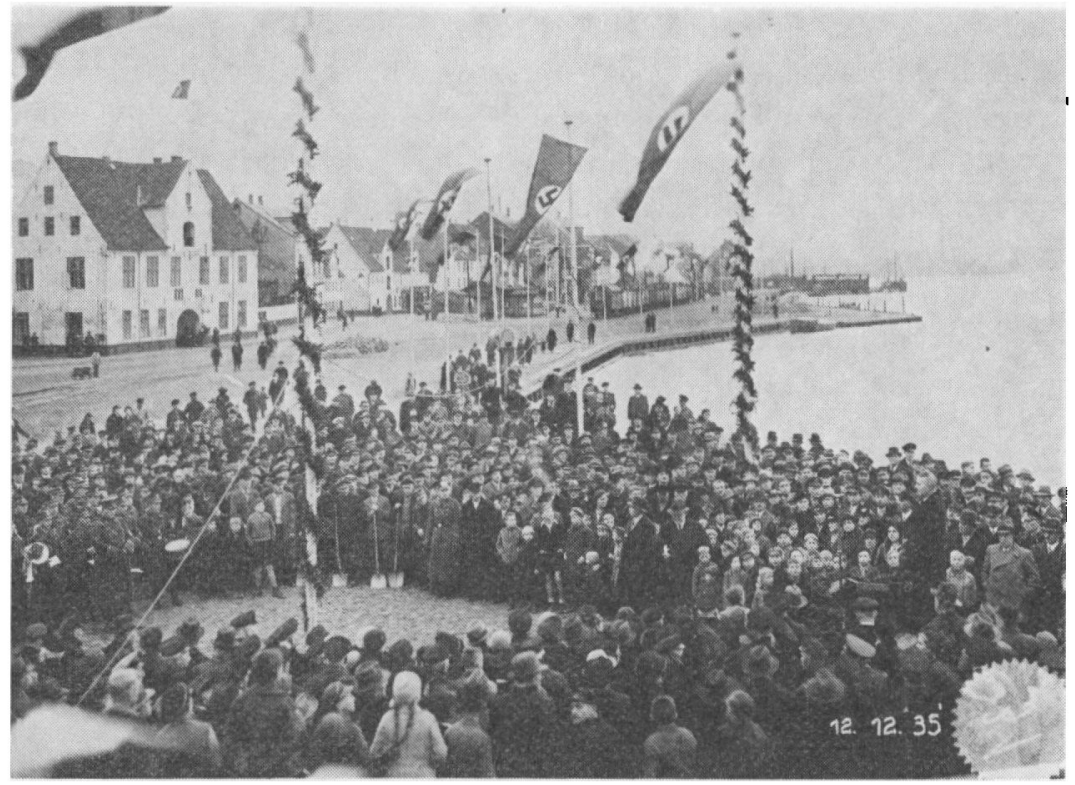

Overborgmester, $d r$. Sievers til bøje $i$ billedet taler ved indvielsen af et nyt bolverksbyggeri i Flensborg 12. dec. 1935.

(Stadtarchiv Flensburg).

retningsfase og indordne det $\mathrm{i}$ den nazistiske forvaltningsstruktur. ${ }^{22}$ Mindre succesrig var Sievers' indsats i Nordslesvig. Hans indblanding i det indre hjemmetyske stridigheder, som havde til formal at samle et enigt tysk mindretal bag en ny nazistisk ledelse, havde kun ført til yderligere splittelse og voksende protester mod den rigstyske indblanding, ligesom det havde vakt opmærksomhed hos den danske presse og $\mathrm{i}$ den danske regering og den danske rigsdag. ${ }^{23}$

\section{Afskedigelsen og samtidens reaktioner}

Den 3. jan. 1936 underskrev dr. Sievers efter lang tids forberedelse Hauptsatzung der Stadt Flensburg, en slags kommunal forfatning, der så at sige betegnede afslutningen på overgangsfasen mellem nazisternes magtovertagelse på kommunalt plan og kommunernes endelige indordning $i$ en ny af nazisterne skabt forvaltningstruktur. ${ }^{24}$ 
Knap en måned senere, den 1. feb. 1936 blev der fra Flensborg rådhus udsendt følgende korte meddelelse: $\gg$ Ved anordning af rigs- og den preussiske indenrigsminister af 27. jan. 1936 er hidtilvarende overborgmester, hr. dr. Wilhelm Sievers i henhold til $\$ 6$ i loven om den faglige embedsstands genoprettelse blevet pensioneret. $\star^{25}$

Denne afskedigelse kom for offentligheden fuldstændigt uventet og vakte voldsom opsigt. Mens de tyske blade undlod at kommentere sagen, formodentlig efter instruks fra propagandaministeriet, fremkom mange gisninger $\mathrm{i}$ den danske presse om årsagen til den pludselige fjernelse af en fremtrædende nazist fra hans post. Nogle danske aviser, bl. a. H. P. Hanssens Hejmdal, Politiken og Aalborg Stiftstidende mindedes $\mathrm{dr}$. Sievers' rolle i forbindelse med grænseflytningskampagnen i foråret 1933 og tydede hans fald som et tegn på afspænding. ${ }^{26}$ Denne teori led dog under den logiske brist, at Sievers' indsats den gang ikke havde hindret hans udnævnelse til landråd og senere til overborgmester flere måneder efter kampagnens afblæsning. Sievers' rolle som talsmand for den slesvig-holstenske grænserevisionisme havde i hvert fald ikke skadet hans karriere. Dertil kom, at han i sin 29 måneders embedstid i Flensborg havde adlydt parolerne fra Berlin og ikke talt om grænseflytning. ${ }^{27}$ Andre blade satte afskedigelsen $\mathrm{i}$ forbindelse med de voldsomme stridigheder mellem de nazistiske fraktioner blandt Nordslesvigs hjemmetyskere, som man fra slesvig-holstensk side havde et væsentligt ansvar for var opstået, og som ikke mindst dr. Sievers havde blandet sig meget aktivt i, uden at det dog var lykkedes at bringe dem til ophør og tilvejebringe den ønskede ensretning. ${ }^{28}$

Det danske mindretals blad i Sydslesvig, Flensborg Avis, betegnede på grundlag af "autentiske underhåndsoplysninger ${ }^{29}$ afskedigelsen som et "rent indrepolitisk, administrativt anliggende" og antydede, at der $\mathrm{i}$ tidens løb havde vist sig nogen meningsforskel mellem to så særprægede personligheder « som overborgmesteren og Gauleiter Lohse. ${ }^{30}$ Sandsynligvis havde bladets redaktionssekretær, redaktør og rådsherre, L. P. Christensen via sit bekendtskab med Sievers fra rådhuset erfaret dette fra hovedpersonen selv. Ellers havde man næppe vovet at bringe en sådan antydning. I Flensborg mente man desuden at vide, at Sievers' forhold til såvel den ny Kreisleiter Oscar Kahle som til hans hidtidige grænsepolitiske rådgiver redaktør Ernst Schröder ligeledes var dårligt. Sidstnævnte skulle således have formået at 
styrke sin position både overfor Lohse og Berlin på Sievers' bekostning. ${ }^{31}$

Den danske generalkonsul i Flensborg Lauritz Larsen fastslog allerede dagen efter afskedigelsen, at Sievers' fald ikke overraskede ham, idet der lange havde bestået personlige modsxtninger mellem overborgmesteren og Lohse. Den pludselighed, hvormed det var sket, havde dog virket overrumplende også på Sievers, som dagen forinden skulle have været til forhandling $\mathrm{i}$ overpresidiet i Kiel og på dette tidspunkt intet have vidst om, at hans afskedigelse var umiddelbart forestående. Særligt fremhævede Larsen, at det over for ham var blevet understreget, at afskedigelsen ikke stod i forbindelse med overborgmesterens grænsepolitiske virksomhed. ${ }^{32}$

Sievers selv var godt klar over, at det var Lohse, der havde sørget for, at han blev fjernet, men var overbevist om; at manden bag Lohse var redaktør Ernst Schröder, der var leder af en grænsepolitisk pressetjeneste Korrespondenzbüro Nordschleswig, og som systematisk skulle have bagtalt ham over for Gauleiter'en og overprxsidenten. Schröder, der desuden var det tyske udenrigsministeriums rådgiver $\mathrm{i}$ slesvigske anliggender, formand for bestyrelsen for det tyske mindretals blad Nordschleswigsche Zeitung og formand for den organisation, som kanaliserede rigstyske midler til det tyske skolearbejde nord for grænsen, Wohlfahrts- und Schulverein für Nordschleswig, var en central person i det tyske grænsearbejde. Foruden Schröder skulle også Sievers' stedfortræder i Flensborg, borgmester Martin Link, rådsherre Kurt Elsner og Kreisgeschäftsführer Hoppe have medvirket til at undergrave Sievers' person i Lohses øjne..$^{33}$

Noget klart billede af situationen forelå altså ikke for samtiden. Det danske mindretals ledelse, som formodentlig fik sine informationer fra Sievers selv, var ikke utilbøjelig til at dele dennes opfattelse. Mindretalsledelsens syn på Ernst Schröder var i forvejen sxrdeles køligt, og Sievers’ version går da også igen i mindretallets officielle historieskrivning. ${ }^{34}$

Sievers forbold til den slesvig-bolstenske overprasident og til det tyske mindretal $i$ Nordslesvig

Det viste sig hurtigt, at Sievers ikke var en mand, der fandt sig $\mathrm{i}$ uden videre at blive skubbet til side, ovenikøbet på en så ydmygende 
måde. Helt utilstedeligt fandt han det, at man havde benyttet den såkaldte Berufsbeamtengesetz, som var blevet gennemført med henblik på at udrense nazismens modstandere i det tyske administrationsapparat. Den 11. feb. 1936 rettede han derfor en henvendelse direkte til Hitlers stedfortræder rigsminister Rudolf Hess, hvori han på 13 maskinskrevne sider talte sin sag og bad partiledelsen om at gribe ind. ${ }^{35}$ Denne skrivelse er registreret som indgået $i$ Hess', stabsledelse den 24. feb. 1936, og herfra rettede lederen af Hess' stab Martin Bormann den 19. marts en forespørgsel til indenrigsminister Frick, ${ }^{36}$ som samtidig tilsendtes Lohse i afskrift. Den 6. april meddelte Lohse partihovedkvarteret i München, at han, da Sievers, som det var fremgået af Bormanns skrivelse, åbenbart ikke ville affinde sig med sin afskedigelse og fortsat søgte at omstøde ministerens beslutning og at bekæmpe ham, havde set sig nødsaget til at indbringe sagen for en partidomstol. Hvis heller ikke dette skulle stoppe Sievers, ville Lohse også forlange en tjenstemandssag rejst. ${ }^{37}$

Sievers havde ramt rigtigt, når han betegnede Lohse som ophavsmanden til sin fjernelse. Dette bekræf tede Lohse selv ganske entydigt i sit brev til Hess den 6. april 1936, hvori han oplyste, at Sievers var blevet afskediget efter en personlig samtale mellem Lohse og Frick. Overpræsidenten tilføjede, at når partihovedkvarteret ikke var blevet underrettet, skyldtes det, at han og Frick havde ment, at Sievers' forseelser var så graverende, at en sådan henvendelse ikke skulle være nødvendig. Lohse afviste videre lidt ulogisk, at der skulle bestå nogen form for meningsforskel mellem ham og den tidligere overborgmester. Skylden for, at det var kommet så vidt som til afskedigelse, lagde han udelukkende på Sievers, som skulle have modarbejdet ham og hans autoritet på en sådan måde, at det $\mathrm{i}$ længden blev uudholdeligt.

Lohse hævdede videre, at han siden 1934 havde vidst, at Sievers modarbejdede ham, og at han allerede dengang havde advaret ham, men kun med det resultat, at Sievers for alvor drog i felten mod ham. For at undgå en afskedigelse af Sievers, havde Lohse aftalt med statssekretær Grauert $\mathrm{i}$ indenrigsministeriet, at Sievers skulle forflyttes til en anden provins. Tidspunktet for denne kontakt mellem Grauert og Lohse har det desværre ikke været muligt at fastslå. Gauleiteren påstod at have informeret Sievers om denne plan, hvilket denne skulle have besvaret med en hånlatter, »mit Hohnlachen «. Denne sidste påstand, som i sig selv forekommer utroværdig, foran- 
ledigede da også sagsbehandleren i Hess' stab til et spørgsmålstegn i marginen. Når Lohse ikke havde rejst tjenestemandssag mod Sievers, skulle det skyldes, at han ville skåne denne, som trods alt var mangeårig partifælle med fire børn, fra at blive afskediget uden pension. Mere sandsynligt forekommer det, at Lohse på forhånd ikke var sikker på udfaldet af en sådan sag. Først da det viste sig, at Sievers ikke ville acceptere sin afskedigelse, men tværtimod modsatte sig den, havde Lohse rejst anklage ved partidomstolen, og han var om nodvendigt rede til også at rejse tjenestemandssag. Overpræsidenten hævdede aldrig at have generet Sievers og tværtimod at have befordret hans karriere, hvilket sidste $\mathrm{i}$ hvert fald var ubestridelig rigtigt. Årsagen til problemerne så Lohse i Sievers' sygelige ærgerrighed. Manden var efter hans opfattelse $» k r a n k h a f t$ pathologisch veranlasst und charakterlich ausserordentlich minderwertig ${ }^{98}{ }^{98}$

Nogen egentlig forklaring på Lohses voldsomme uvilje mod Sievers giver overpræsidentens fremstilling egentlig ikke. Han var tydeligvis opbragt over, at Sievers ikke bare fandt sig i sin skæbne; men allerede tidligere havde Sievers ved forskellige lejligheder pådraget sig overpræsidentens mishag, således da han i sommeren 1934, den 16. juni, på egen hånd rettede en henvendelse direkte til det preussiske indenrigsministerium vedrørende størrelsen af de pensionsbeløb, som Flensborg by måtte udrede til de pensionerede overborgmestre Todsen og $\mathrm{v}$. Hansemann. Sievers havde frivilligt ladet sig indplacere på et forholdsvis lavt løntrin og fandt det urimeligt at skulle udbetale pensionsbeløb højere end den fungerende overborgmesters løn. Sievers fulgte $i$ sin egenskab af Gauamtsleiter für Kommunalpolitik emnet op ved flere lejligheder uden dog at vinde gehør i ministeriet, som $\mathrm{i}$ stedet tilbød ham at blive rykket op på et højere løntrin. ${ }^{39}$

Sievers handlede ikke blot $i$ denne sag efter Lohses opfattelse for selvstændigt og "ohne vorhergehende Fühlungnahme mit den politischen Stellen «.40 Også nogle udtalelser, som Sievers fremsatte over for en dansk journalist under en cykeltur $i$ Danmark $i$ sommeren 1934, gav anledning til en irettesættelse fra overpræsidenten. ${ }^{41}$

Den 12. juni 1935 modtog Sievers en næse fra overpræsidenten, fordi han havde afholdt et kursus for tyske kommunalpolitikere fra Nordslesvig i Flensborg. ${ }^{42}$ Baggrunden herfor var følgende. Den 14. maj 1935 forkyndte Hejmdal i stor opsætning: "Tysk nationalsocialistisk indblanding i danske indrepolitiske forhold. Overborgmester 
dr. Sievers kommanderer medlemmer af danske kommunalbestyrelser til møde i Flensborg «. Grundlaget for Hejmdals påstand var en skrivelse, som bladet var kommet $i$ besiddelse af, fra lederen af den ene af de stridende nazistiske fraktioner, NSAN, Jep Nissen, som beordrede alle partifæller, der havde sæde i amtsråd, byråd eller sogneråd til et tjenstligt møde $\mathrm{i}$ Det tyske Hus i Flensborg den 13. maj 1935. Jep Nissen opfattedes i danske kredse korrekt som Sievers' mand; men begge afviste, at overborgmesteren skulle have haft noget som helst med dette arrangement at gøre, og Hejmdal var da heller ikke $\mathrm{i}$ stand til at føre bevis for sin påstand.43 Lohse synes derimod at have ladet sig overbevise af de danske påstande.4

Sievers følte sig på grund af disse gentagne tilrettevisninger uretfærdigt behandlet, idet han mente at have handlet, som han gjorde, for sagens skyld og $\mathrm{i}$ den nazistiske bevægelses interesse. Samtidig følte han, at Lohse bevidst gik uden om ham, idet overprxsidenten ved sine besøg i Flensborg kun tog kontakt med borgmester Link. Det lykkedes derfor ikke Sievers ved hjalp af en personlig samtale at få opklaret, hvad han betragtede som mindre misforståelser. Allerede $\mathrm{i}$ efteråret 1934 havde han omtalt dette for Ernst Schröder, som ville forsøge at tilvejebringe en forsoning. ${ }^{45}$

Når det bestående en smule spæendte forhold for alvor skærpedès $i$ efteråret 1935 skyldtes det Sievers' åbenmundethed. Således havde han under en samtale med dr. Laux fra regeringspræsidiet i maj eller juni betegnet Lohses stedfortrxder som Gauleiter Wilhelm Sieh som den tåbeligste person, han havde truffet i sit liv. ${ }^{46}$

Endnu mere fatale var de udtalelser, som Sievers under en tjenstlig samtale med dr. Laux den 15. okt. 1935 lod sig foranledige til at fremsætte under en drøftelse vedrørende udvælgelsen af rådsherrer i Flensborg. Sievers bemærkede, at den NSDAP-befuldmægtigede Claus Hans, som efter overborgmesterens opfattelse var en novice i forvaltningsanliggender, beredte ham vanskeligheder. ${ }^{47}$ Siden kom samtalen også ind på en dom, som den overste partidomstol havde afsagt $i$ en eksklusionssag mod Sievers' sekretariatschef August Hansen. Denne var mod Lohses onske ikke blevet udelukket af partiet. På dette tidspunkt forlod August Hansen, som også havde været til stede, drøftelsen. Sievers skulle dernæst have forhørt sig om, hvorvidt rygter om, at han skulle afløse Altonas overborgmester Brix, var korrekte. Under diskussionen af dette spørgsmål lod Sievers falde en 


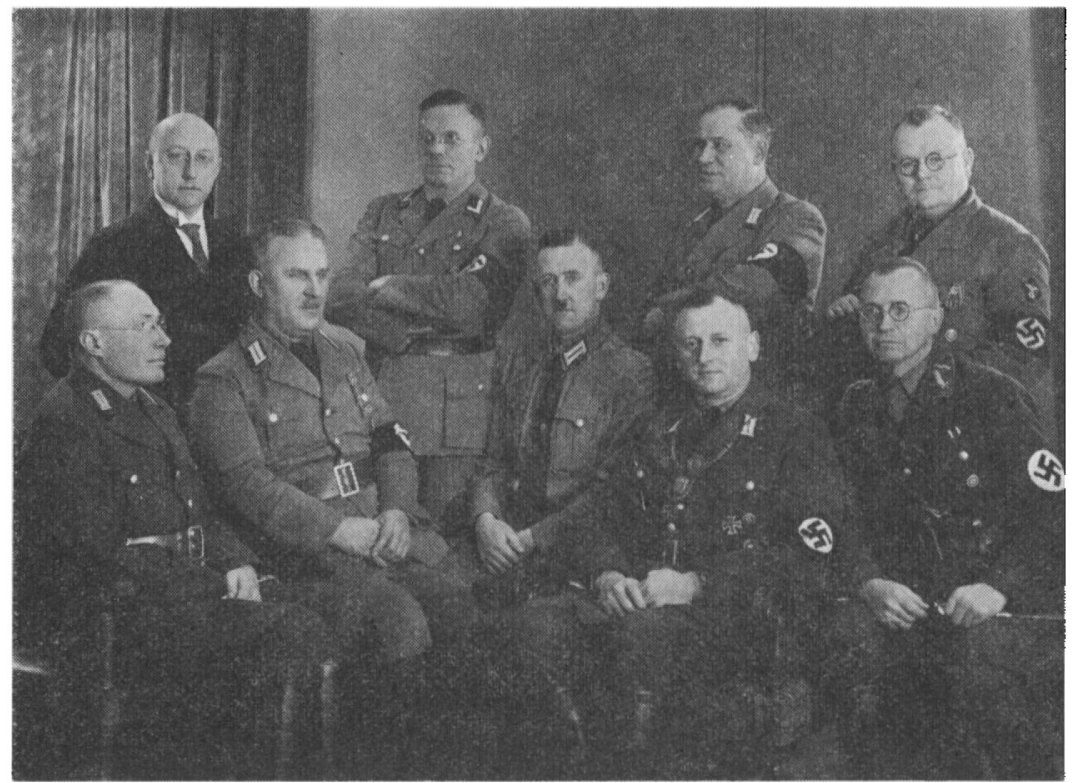

Flensborgs magistrat 1935. Overborgmester Sievers sidder som $n r .2$ fra bojre $i$ forste rekke. (Stadtarchiv Flensburg).

bemærkning om, at Lohses position sagdes at være svækket, fordi han ikke forstod at samarbejde med marinen, ligesom der herskede almindelig misstemning over, at Gauleiter'en ikke var til at træffe for gamle partifæller, fordi han altid var på jagt. "Der Kerl soll doch nicht vergessen, was er gewesen und woher er gekommen sei.* Ved Hitlers besøg i Kiel skulle der være blevet lagt en hel pakke med klager over Lohse i Førerens bil, ligesom det forlød, at han havde mistet ledelsens tillid og skulle forflyttes til Hannover som overpræsident. I Slesvig-Holsten skulle han afloses af forhenværende viceadmiral, daværende landråd i Slesvig kreds, Kolbe som overpræsident, mens Hamborgs Gauleiter Karl Kauffmann skulle overtage partiledelsen. ${ }^{48}$

Med disse udtalelser var Sievers' skæbne beseglet. Uanset et gen- 
sidigt lofte om tavshed refererede dr. Laux Sievers' bemærkninger for en kollega, ligesom han tjenstligt informerede regeringspresident Wallroth. Straks efter anmodede også overpresidenten om en skriftlig beretning. Denne modtog Lohse den 6. nov. 1935, og straks den følgende dag skrev han til Sievers og forlangte en forklaring, samtidig med at han meddelte Sievers, at han ikke mere onskede at samarbejde med ham og ville bede ministeriet om at forflytte ham fra Slesvig-Holsten.98

Sievers fik overrakt dette brev personligt af kredsleder Kahle umiddelbart før sin afrejse til München til et møde på årsdagen for Hitlers mislykkede kupforsøg i 1923.

Straks efter at have modtaget Lohses brev begav Sievers sig til Slesvig for at opsøge regeringspræsident Wallroth, som han traf $i$ dennes hjem. Wallroth erklerede imidlertid uventet for Sievers, som mente at have et godt forhold til regeringsprasidenten, at han ikke kunne tvivle på dr. Laux' udsagn. Sievers bad dernæst Wallroth om at konfrontere ham med Laux, hvilket regeringspræsidenten afviste under henvisning til, at sagens akter allerede var overgivet til overpræsidenten. Wallroth foreslog ham i stedet at tale med Lohse, som imidlertid nægtede at modtage ham. Den 9. nov. anmodede Sievers i stedet skriftligt Lohse om at få sendt en afskrift af Laux' referat, så han kunne få lejlighed til at retfærdiggøre sig, helst ved en personlig samtale. Den 12. november sendte Lohse det ønskede referat, men nægtede fortsat at modtage Sievers personligt. Den 18. november svarede Sievers og bestred $i$ alt væsentligt dr. Laux' udsagn, som han hævdede var en forvanskning af hans udtalelser, ligesom Laux havde udeladt alt, hvad der kunne være ubehageligt for ham selv. Sievers indrømmede at have omtalt nogle verserende rygter om Lohse, men nægtede at have fremsat nogen form for fornærmende kommentarer. Sievers hørte herefter ikke mere fra Lohse og gik, efter hvad han selv skriver i sine erindringer, ud fra, at man ikke ville kunne gøre ham noget. ${ }^{50}$

Den 7. december 1935 afholdtes et møde under forsæde af Lohse med deltagelse af regeringspræsident Wallroth, vicepræsident $\mathrm{dr}$. Schow, Laux og Sievers, hvilket sidstnævnte ikke nævner i sine erindringer. Sievers fik her lejlighed til at tale sin sag. Et referat af dette møde har eksisteret, men er ikke blandt de bevarede akter. Det vides kun, at begge parter holdt fast ved deres forklaringer, hvorefter 
Wallroth den 18. jan. 1936 bad ministeriet afskedige Sievers i henhold til $\$ 6$ i Berufsbeamtengesetz. Overpræsident Lohse kunne selvfølgelig tilslutte sig denne ansøgning, som øjeblikkelig blev bevilget, og den 27. jan. 1936 underskrev rigsindenrigsministeren bekendtgorelsen som Sievers' afskedigelse. ${ }^{31}$

Sievers' grænsepolitiske virksomhed og hans rolle i forbindelse med nazificeringen af det tyske mindretal i Nordslesvig synes altså ikke at have været inddraget $i$ sagen. Spørgsmålet er imidlertid, om det er forsvarligt helt at lade Sievers' grænsepolitik ude af betragtning, når det gælder om at analysere årsagerne til hans fald.

I efteråret 1934 beklagede lederen af det tyske mindretal i Nordslesvig, folketingsmand pastor Johs. Schmidt-Vodder sig over, at slesvig-holstenerne havde påtvunget mindretallet nazismen i rigstysk udgave. Særlig rettede hans harme sig imod Sievers, som han mente ved et bevidst intrigespil søgte at udmanøvrere den hjemmetyske folketingsmand. Schmidt-Vodder anså Sievers (og Peperkorn) for at være de hovedansvarlige for den splittelse, som havde hersket inden for mindretallet siden den nazistiske magtovertagelse i Tyskland. Disse anklager mod Sievers for at være Nordslesvigs onde ånd rettede Schmidt-Vodder $i$ et memorandum til Volksdeutscher Rat, det organ, som af Førerens stedfortræder Hess havde făet overdraget ledelsen af den tyske grænse- og nationalitetspolitik. Årsagen til, at Schmidt-Vodder særligt kastede sig over Sievers, kunne være, at han netop i efteråret 1934 havde fået, ganske vist ubekræf tede, informationer om, at Sievers ville miste sin grænsepolitiske nøglestilling. Omtrent samtidig dukker for forste gang antydninger op om meningsforskelle mellem Lohse og Sievers, og $\mathrm{i}$ følge lederen af det tyske udenrigsministeriums presseafdeling Alex. Bogs overvejede man i Berlin at lade Sievers falde. ${ }^{52}$

Foreløbig skete der dog intet $\mathrm{i}$ denne retning. Udenrigsministeriet var imidlertid fortsat kritisk over for Sievers' politik i Nordslesvig, selv om han havde skrinlagt grænserevisionskravet. Ikke kun Schmidt-Vodder anså Sievers for at være hovedansvarlig for det tyske mindretals indre splittelse. Også den tyske gesandt i København v. Richthofen, Krahmer-Möllenberg fra Deutsche Stiftung, det organ, der administrerede den statslige økonomiske hjælp til de tyske mindretal, og den uofficielle leder af det tyske skolevæsen i Nordslesvig, Regierungsdirektor Claus Petersen i Slesvig, der tillige var 
Deutsche Stiftungs tillidsmand, så med skepsis på Sievers' Nordslesvig-politik. Desuden rettede den danske presse voldsomme direkte angreb på Sievers, angreb, som ganske vist tilbagevistes fra tysk side, men som bidrog til at undergrave Sievers' stilling. ${ }^{53}$

I juni 1935 foretog Legationsrat Schwager fra det tyske udenrigsministerium en rejse i granseområdet, hvor han havde samtaler med en rakke tyske grænsepolitikere. Af hans notater fremgår, at Peperkorn nu var blevet kørt ud på et sidespor, men at Sievers fortsat hævdede sin position i Nordslesvig-anliggender, selv om hans indflydelse af mange betragtedes som skadelig. Således erklærede Regeringsprxsident Anton Wallroth og Regierungsdirektor Claus Petersen begge, at også Sievers' imødekommenhed over for det danske mindretal i Flensborg syntes uhensigtsmæssig og alligevel ikke foranledigede den danske regering til at betragte hans virksomhed i Nordslesvig med mildere øjne. Fortroligt var Schwager tillige blevet underrettet om en plan om at forflytte Sievers til Altona som overborgmester. Bag denne plan skulle stå Claus Petersen og Ernst Schröder. Schwagers kilder havde dog udtrykt nogen tvivl om, hvorvidt Lohse skulle være tilbøjelig til at fjerne Sievers fra Flensborg. Også gesandt v. Richthofen og den tyske konsul i Åbenrå betragtede Sievers' fjernelse som ønskelig. ${ }^{54}$

Afgørende var imidlertid Lohses holdning. Endnu i sommeren 1935 var der uklarhed om, hvorvidt overpresidenten var villig til at lade Sievers falde. Midt i juni 1935 tog Lohse et initiativ i et forsøg på at løse det tyske mindretals ledelsesproblemer. Sammen med Claus Petersen tog han kontakt med de forskellige fraktionsførere nord for grænsen. For pastor Schmidt-Vodder var betingelsen for en overenskomst, at Sievers blev fjernet, ikke blot som overborgmester, men også fra formandsposten i SHB. ${ }^{55}$ Omtrent på samme tidspunkt havde Lohse faktisk bedt Sievers være rede til at overtage overborgmesterposten i Altona. Dette kunne tyde på, at Lohse agtede at forsøge at slå to fluer med et smæk, nemlig at få løst problemerne i Nordslesvig, hvilket Sievers var blevet en hindring for, og ved at få Sievers placeret i provinsens storste by Altona, at fă udskiftet den uduelige overborgmester Brix med en kompetent forvaltningsembedsmand. Laux' referat af samtalen med Sievers fik åbenbart Lohse til også at lade denne plan falde og i stedet at beslutte at søge Sievers fjernet helt fra Slesvig-Holsten. ${ }^{56}$ 


\section{Sievers' appel $i$ afskedigelsessagen}

I sin appel til Førerens stedfortræder den 11. feb. 1936 understregede Sievers, at der ikke kunne anføres eller var blevet rejst klager over hans embedsførelse, som kunne begrunde en afskedigelse. "So bleibt also nichts als die Tatsache: ich habe den Oberpräsidenten und Gauleiter verärgert. « Dette havde han fået bekræftet ved en henvendelse $\mathrm{i}$ indenrigsministeriet. Heroverfor havde hans dygtighed, »anständiges Benehmen « og hans nazistiske fortid åbenbart ingen vægt. ${ }^{57}$

Den lokale slesvig-holstenske Gaugericht, som også Sievers havde henvendt sig til, var ikke meget for at påtage sig denne sag, og formanden Gaurichter dr. Lütt, der tidligere havde været Lohses personlige àdjudant, bad derfor den øverste partidomstol, Oberstes Parteigericht i München, om at overtage den og fremsendte tillige sagens akter. Dr. Lütt motiverede denne fremgangsmåde med, at Gaugericht ellers ville udsatte sig for dels at skulle efterprove en af rigsindenrigsminister Frick truffet beslutning, og dels at skulle beskæftige sig med "en række beskyldninger ... rettet mod Gauleiter Lohses person. ${ }^{58}$ Det var denne varme kartoffel, man gerne så den øverste partidomstol overtage.

Bormann var ikke uenig i disse betragtninger. Den 25. maj 1936 sendte han Sievers' og Lohses henvendelser til den overste partidomstol og bemærkede, at han anså det for umuligt at lade en lokal partidomstol tage sig af sagen, når Gauleiter'en selv var part $i$ denne. Bormann bad tillige retten fremskynde sagens behandling. ${ }^{59}$ Den 13. juni beklagede dr. Sievers sig til den øverste partidomstol over, at det, så vidt han var orienteret, så ud til, at retten overhovedet ikke ville beskæf tige sig med hans hovedanke, nemlig at man havde benyttet Berufsbeamtengesetz mod et mangeårigt partimedlem..$^{60}$

Den 17. juni 1936 afsagde retten en foreløbig kendelse $i$ sagen gående ud på, at, hvis Sievers havde udtalt sig om Gauleiter og overpræsident Lohse, som hævdet $\mathrm{i}$ anklageskriftet, ville han være skyldig $i$ et groft brud på partidisciplinen og $i$ partiskadelig virksomhed. Samtidig fastsattes det egentlige retsmøde til den 3. juli 1936 i Flensborg. Som vidner skulle indkaldes Regierungsrat dr. Ernst Laux fra Slesvig, Regierungsdirektor Claus Petersen, ligeledes Slesvig, Bürodirektor August Hansen fra Flensborg, redaktør Ernst Schröder og borgmester Martin Link fra Flensborg. ${ }^{61}$ 
Anklagen gik $\mathrm{i}$ korthed ud på, at dr. Sievers under en tjenstlig samtale med Regierungsrat dr. Laux fra regeringsprxsidiet i Slesvig i oktober 1935 skulle have nedvurderet Gauleiter Lohses person win gehässiger Form \& og "zum Zwecke der Verächtlichmachung ${ }_{\alpha .}{ }^{62}$ Den 26. juni 1936 udvidedes anklagen med endnu et punkt. I februar 1936, altså efter sin afskedigelse, skulle Sievers have foranlediget en partifælle, Oberzollsekretär Wilhelm Dinse, til at give oplysninger fra toldvæsenets akter om borgmester Links forhold (Link var blevet anklaget for en deviseforseelse), hvorved han havde forledt en embedsmand til en tjenesteforseelse. Også til dette punkt indkaldtes et antal vidner.

Den 3. juli 1936 fandt retsmødet sted, og samme dag afsagde den øverste partidomstol sin kendelse. Dr. Sievers blev fundet skyldig i partiskadelig adfærd, omend under stærkt formildende omstændigheder, hvorfor udelukkelse af partiet blev fundet at være for hård en straf. I stedet tildeltes Sievers en advarsel og blev frakendt retten til at beklæde tillidsposter i partiet for et år, d.v.s. indtil den 30 . juni 1937, hvilket Sievers fik officiel underretning om i en skrivelse fra Førerens stedfortræder $\mathrm{i}$ august $1936 .{ }^{64}$ Den 4. marts 1937 søgte Sievers den øverste partidomstol om at få genoptaget sagen under henvisning til en række påståede fejl eller ukorrektheder $\mathrm{i}$ dommens præmisser. ${ }^{65}$

Påfaldende nok benægtede han ikke, som han tidligere havde gjort, uden at retten havde frstet lid hertil, at have udtalt sig nedsettende om Lohses stedfortræder Sieh, men forsvarede sig i stedet med, at Sieh dengang ikke havde været stedfortrædende Gauleiter, men kun Gaukassenwart og dermed Sievers' ligemand i rang. Ejheller forsøgte han at bestride dr. Laux' udsagn, men henviste tværtimod til, at hans udtalelser om Lohse var det eneste, der var tilbage af alt det materiale, man havde samlet imod ham. ${ }^{66}$ En forklaring herpå kunne være, at retten på disse punkter nu engang havde besluttet at freste lid til dr. Laux, og at Sievers ikke var i stand til at fremføre afgørende argumenter for, at domstolen i stedet skulle tro på hans forklaring. Den 2. juli 1937 afviste den øverste partidomstol en ny sagsbehandling, idet man fandt de af Sievers fremførte argumenter dels for ubetydelige $\mathrm{i}$ forhold til de fastslåede kendsgerninger til at kunne retfærdiggøre en mildnelse af en allerede meget mild dom, dels på et enkelt punkt ikke troværdige. Sievers havde desuden anfægtet vidnet Ernst 


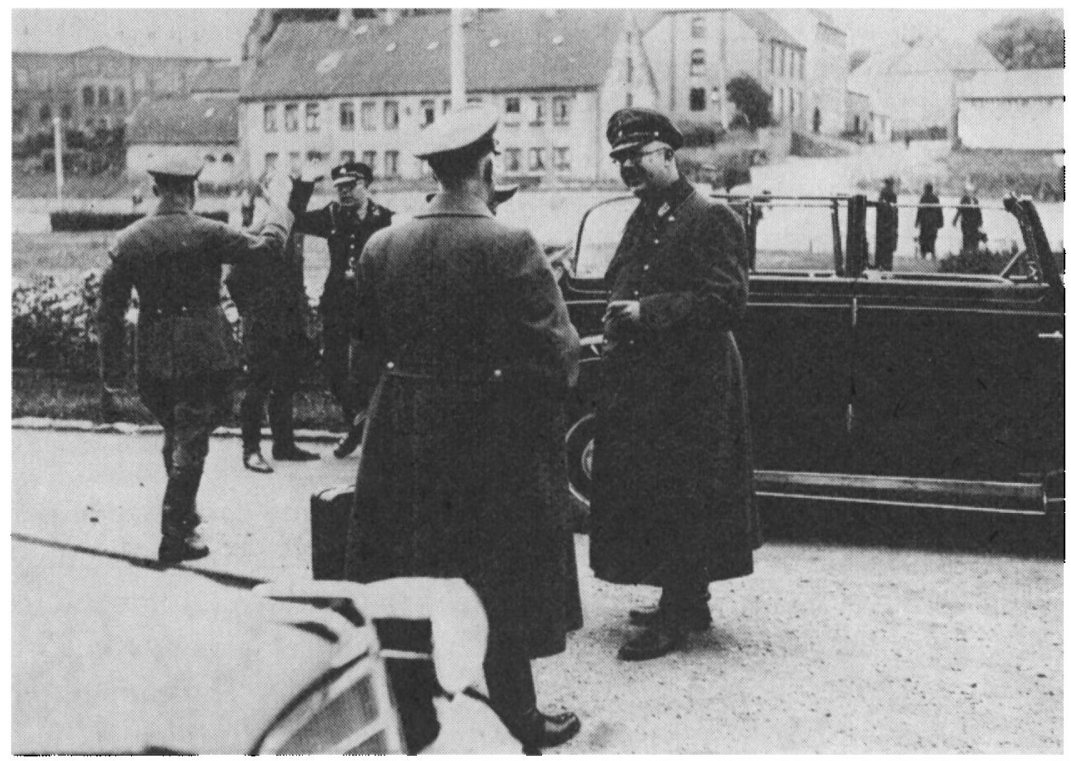

Den slesvig-holstenske Gauleiter Lohse yderst til bøjre under et besøg i Flensborg 1934. (Stadtarchiv Flensburg).

Schröders troværdighed, hvilket efter rettens opfattelse var uden betydning, eftersom dommen først og fremmest hvilede på dr. Laux’ udsagn, om hvis troværdighed retten ikke var i tvivl. ${ }^{67}$

Dr. Sievers nåede altså ikke ad rettens vej sit mål at blive rehabiliteret og genindsat $i$ sin stilling, som Lohse $i$ ørigt $i$ hast havde sørget for at få besat. Der skal ikke her tages stilling til, om den øverste partidomstols kendelse var rimelig. Om Sievers havde udtalt sig om Lohse, som hævdet af dr. Laux, eller ej, er i denne forbindelse mindre vigtigt. Lohse troede det $\mathrm{i}$ hvert fald.

Sievers' ønske om at få kendt sin afskedigelse ugyldig og dermed blive fuldt rehabiliteret gik ikke $\mathrm{i}$ opfyldelse. Hans stædige vægring ved at acceptere den måde, hvorpå han var blevet behandlet, var dog ikke uden resultater. Sievers' påpegning i brevet til Hess af 11. feb. 1936 af, at Berufsbeamtengesetz ikke burde og kunne anvendes $i$ hans tilf $æ l d e$, medførte, at Hess den 12. marts meddelte indenrigsministeriet, at Sievers rent faktisk havde ret på dette punkt. ${ }^{88}$ Som følge heraf meddelte Frick den 11. maj samme år Førerens stedfortræder, at 
han var enig på dette punkt, og instruerede samtidig ved et reskript af 11 . maj 1936 forvaltningen herom. ${ }^{69} \mathrm{Da}$ Frick således selv havde erkendt, at i hvert fald proceduren ved Sievers' afskedigelse havde været ukorrekt, kunne han vanskeligt modsætte sig rigspartiledelsens ønske om en ny tilsvarende stilling til Sievers. Den 4. februar 1938 blev han, som det hedder "auf ausdrücklichen Wunsch des Stellvertreters des Führers, der Kanzlei des Führers und des Reichsministers des Innern « udnævint til overborgmester i Brandenburg. ${ }^{70}$

Den 21. maj 1938 ansøgte Sievers, hvilket han var nødt til, om optagelse i SS, og i oktober samme år modtog han besked om, at hans ansøgning var godkendt og samtidig en udnævnelse til SS-Sturmbannführer. ${ }^{71}$ Kort tid forinden havde han modtaget en skrivelse fra den øverste partidomstol, ifølge hvilken dommen over ham var blevet ophxvet som et led $i$ en amnesti af 27 . april $1938 .{ }^{72}$ Dermed var hans partimæssige generalieblad $\mathrm{i}$ hvert fald $\mathrm{i}$ princippet igen rent. Sievers var dog endnu ikke helt tilfreds. I december 1938 indsendte han, som fra den 1. oktober 1928 til november 1935 havde været Gauamtsleiter für Kommunalpolitik i Slesvig-Holsten, en officiel ansøgning om at fă lov at bære uniform som Gauamtsleiter, men modtog det svar, at Gau Schleswig-Holstein havde protesteret herimod. ${ }^{73}$ Sievers synes at have måttet bøje sig herfor, men efter krigsudbruddet, $\mathrm{i}$ marts 1941, henvendte han sig igen efter en personlig samtale skriftligt til Reichsamtsleiter dr. Jobst i NSDAP-ledelsens Kommunalpolitisches Amt. Sievers påpegede, at han var fuldt rehabiliteret, og at der derfor ikke mere var nogen saglig grund til at nægte ham at bære den uniform, han ønskede, og bad om at få forholdet bragt $\mathrm{i}$ orden. ${ }^{74}$ Det fremgår ikke af akterne, om Sievers fik sit ønske opfyldt. Derimod er det klart, at han fortsat ufortrødent bestræbte sig på, at få selve sin afskedigelse i Flensborg erklæret for ulovlig. Så sent som den 17. april 1944 skrev chefen for Reichssicherheitshauptamts III afd. til statssekretær Stuckart i indenrigsministeriet og bad under henvisning til, at Berufsbeamtengesetz netop som følge af Sievers-sagen ikke mere måtte anvendes på gamle nazister, og til Sievers' smukke karakter i øvrigt om, at hans pensionering af 27. januar 1936 måtte blive ophævet. ${ }^{75}$

Stuckart var i og for sig ikke uenig heri, men tilføjede i marginen på dette brev, at hvis man ophævede denne pensionering, ville Sievers igen være Flensborgs retmæssige overborgmester. "So geht es nicht«. 
Det væsentligste var jo alligevel, at $» S$. in Ehren wieder verwendet worden ist « ${ }^{76}$ Resultatet blev, at det ved en samtale den 2. juni 1944 mellem dr. Neesse fra Rigspartiledelsen og Ministerialrat dr. Hoffmann fra indenrigsministeriet blev aftalt, at ministeriet skulle meddele Sievers, at efter gældende praksis ville hans tilfælde ikke være blevet behandlet, således som det var sket i $1936 .{ }^{77} \mathrm{Pà} \mathrm{dette} \mathrm{tidspunkt}$ havde spørgsmålet vel $\mathrm{i}$ øvrigt nærmest akademisk interesse. I april 1945 erobrede Den røde Hær Brandenburg, og Sievers flygtede mod vest. I begyndelsen af maj 1945 overgav han sig til amerikanerne efter at være svømmet over Elben. ${ }^{78}$

\section{Konklusion}

Det kan altså betragtes som fastslået, at der ved afskedigelsen af overborgmester Sievers i januar 1936 ikke var tale om nogen form for udenrigspolitisk tilkendegivelse over for Danmark. Sievers' fald skyldtes uoverensstemmelser mellem ham og overpræsident, Gauleiter Lohse. Forholdet mellem de to havde været præget af visse gnidninger og mindre uoverensstemmelser lige siden efteråret 1934, og blandt årsagerne hertil bør fremhæves Sievers' politik i Nordslesvig, som i stedet for den tilstræbte enige opslutning bag en ny nazistisk mindretalsledelse kun skabte splittelse inden for mindretallet og åbenlys debat $\mathrm{i}$ den danske presse om rigstysk indblanding $\mathrm{i}$ interne danske forhold. Det bør imidlertid tilføjes, at denne politik, som bragte Sievers $i$ et modsætningsforhold til indflydelsesrige kredse både $i$ Nordslesvig, Slesvig-Holsten og Berlin, fra begyndelsen også var Lohses politik, og at det kun var Sievers' efter Gauleiterens opfattelse ubehændige optræden ved visse lejligheder, som påtaltes. Omvendt mente Sievers, at disse påtaler var uretfærdige. Det er dog ikke sandsynligt, at det var disse mindre sager alene, som foranledigede Lohse til at overveje at forflytte Sievers til Altona som overborgmester, men ligeså meget nødvendigheden af at fjerne Altonas uduelige overborgmester Brix og erkendelsen af, at Sievers' person stod $i$ vejen for Lohses fornyede forsøg i sommeren 1935 på at tilvejebringe en løsning i Nordslesvig.

Sikkert er det under alle omstændigheder, at årsagen til Lohses beslutning om fuldstændig at fjerne Sievers og indlede sag mod ham ved den øverste partidomstol med krav om hans udelukkelse af par- 
tiet var dr. Laux' skriftlige beretning om Sievers' udtalelser ved mødet i regeringspræsidiet den 15. okt. 1935. Dette fremgår klart af dommens præmisser, som dog samtidig henviser til nogle uspecificerede »formildende omstændigheder $*$, som skulle begrunde, at retten ikke havde fulgt Lohses onske om Sievers' udelukkelse af partiet. Det er sandsynligt, at den kendsgerning, at proceduren ved Sievers' afskedigelse måtte betegnes som ukorrekt, har spillet en rolle. Den anklagedes mangeårige partimedlemsskab og rigspartiledelsens interesse for hans sag, som ydermere senere førte til en så fuldstændig rehabilitering, at det $i$ realiteten betød en desavouering af Lohse, har givetvis også været af væsentlig betydning. Når retten ikke frikendte ham fuldstændigt, skyldtes det næppe formaljuridiske hensyn. Sluttelig var der tale om en sag, hvor påstand stod mod påstand. Lohse skulle imidlertid stilles tilfreds i rimelig grad og - som statsekretær Grauert i indenrigsministeriet skulle have sagt til Sievers i februar 1936 "Statsræson'en kræver, at ingensomhelst kritik rettes mod Gauleiter'en. * $^{70}$

Når referater af de øvrige vidneudsagn for den øverste partidomstol ikke er blandt de bevarede akter eller blot omtalt $\mathrm{i}$ dommens præmisser, må det betyde, at retten ikke tog eller $\mathrm{i}$ hvert fald ikke ønskede at se ud til at have taget hensyn til dem. Sievers selv betragtede særlig Ernst Schröders udsagn som belastende for ham og gav udtryk for, at denne ved sine manipulationer så at sige skulle have udarbejdet drejebogen for $» d r$. Sievers' fald «. Dette lader sig ikke bevise, lige så lidt som det har været muligt at bekræfte Sievers teori om en vel iscenesat sammensværgelse med henblik på at fælde ham. Derimod er det meget vel tænkeligt, at Sievers' mange indflydelsesrige modstandere, da de med dr. Laux' referat virkelig havde fået håndgribeligt materiale at føre i marken mod ham, har lagt pres på Lohse for at få Sievers fjernet helt $\mathrm{i}$ stedet for blot forflyttet fra Slesvig-Holsten, som der taltes om i Lohses brev til Sievers den 7. nov. 1935. Sievers' grænsepolitik kan altså højst have haft indflydelse på formen for hans fjernelse, ikke på selve sagen.

\section{Efterskrift}

Efter at Sievers ved det tyske sammenbrud havde overgivet sig til amerikanerne, forblev han interneret indtil juni 1947. Efter sin løs- 
ladelse lykkedes det for ham at få en stilling $i$ et advokatfirma i Kiel. I 1951 overtog han posten som juridisk rådgiver og fuldmægtig for Landesverein für Innere Mission. I 1949 meldte han sig ind i CDU og blev i 1951 valgt som borgerrepræsentant i Kiel og overtog samtidig en post som rådmand for byens sygehus. Han blev formand for CDU i Kiel, og efter at de borgerlige partier i 1955 havde erobret flertallet $\mathrm{i}$ byrådet, blev han valgt til bypresident. Allerede i 1957 trådte han imidlertid tilbage fra sin post som formand for CDU i Kiel, og da man $i$ juni 1959 ville flytte ham fra placeringen som spidskandidat på CDU-listen til en af de nederste pladser, nedlagde han sit embede og meldte sig ud af partiet. I 1960 blev han valgt som formand for Allgemeiner Kieler Kommunalverein, en stilling, som han beklædte indril 1965. Dr. Sievers døde den 1. juli $1966 .{ }^{80}$

\section{KILDER OG LITTERATUR}

Forkortet DCB

FIAA

KFIA

StAFl

Erinnerungen

Fl bys Hist

Flensburg

Lenzing

Gedächtnisschrift Kai Detlev Sievers (Udg): Wilhelm Sievers 1896-1966. Eine Gedächtnisschrift. Kiel 1967.

Sydslesvig gennem Tiderne, bd. I. 1949.

Tägil

Utrykt materiale:

Document Center Berlin

NSDAP Zentralkartei, Parteikorrespondenz, SS-Führer, OPG (Oberstes Parteigericht) und Verschiedenes: SIEVERS, Wilhelm Dr. geb. 2. 12. 1896 in Kiel.

Dansk Centralbibliotek, Flensborg

Flensborg Avis' arkiv, ks. 25.

Rigsarkivet, København

Kgl. Konsulat Flensborgs arkiv, j. nr. 7. y. 2. u.

Stadtarcbiv Flensburg

Flensborg bys arkiv, II. C. 187.

Erinnerungen des Flensburger Oberbürgermeisters Dt. Sievers an seine Amtszeit in Flensburg 1933-1936.

\section{Trykt materiale:}

Flensborg bys Historie, bd. II. 1955.

Flensburg. Geschichte einer Grenzstadt. Flensborg 1966. Hilke Lenzing: Die deutsche Volksgruppe in Dänemark und das nationalsozialistische Deutschland (1933-1939). Bonn 1973.

Sven Tägil: Deutschland und die deutsche Minderheit in Nordschleswig. Stockholm 1970. 
FlA

\section{Periodika}

Flensborg Avis

Grænsevagten

Hejmdal

mmfl.

\section{HENVISNINGER OG NOTER}

1. Gedächtnisschrift, s. 7-8. DCB, Dr. Wilhelm Sievers: Lebenslauf, udat. (ca. 1938).

2. DCB, Dr. Wilhelm Sievers: Lebenslauf, udat. (ca. 1938).

3. Gedächtnisschrift, s. 8.

4. Se note 2.

5. Se note 3.

6. Se note 2.

7. Gedächtnisschrifr, s. 9.

8. Se note 2.

9. Erinnerungen, s. 7 .

10. Tägil, s. 23-24, Lenzing, s. 32-33, Erinnerungen, s. 81.

11. Erinnerungen, s. 82-83.

12. Lenzing, s. 33.

13. Cit. efter Lenzing, s. 35.

14. Tägil, s. 41-42.

15. Lenzing, s. 43, Tägil, s. 40.

16. Lenzing, s. 44, Tägil, s. 39.

17. Lenzing, s. 33.

18. Erinnerungen, s. 16-17.

19. Grænsevagten 1933, s. xx.

20. Erinnerungen, s. 15.

21. Erinnerungen, s. 15-17.

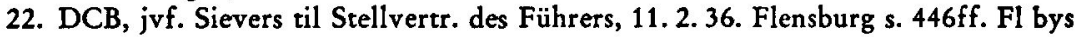
Hist II, s. 368ff.

23. Tägil, s. 70-71.

24. StAFl II. C. 187, Hauptsatzung der Stadt Flensburg, 3.1.1936.

25. Cit. efter FIA 2. 2. 1936.

26. Hejmdal 3. 2. 36.

27. Sydslesvig gennem Tiderne I, s. 557.

28. Bl. a. Social-Demokraten.

29. Se Sydslesvig gennem Tiderne I, s. 557.

30. FIA 2. 2. 1936.

31. Se note 29.

32. KFIA 7. y. 2. u., L. Larsen til Udenrigsministeriet, no. 94, 1. 2.1936.

33. FIAA ks. 25, Håndskrevne referater af personlige samtaler mellem Sievers og rådsherre L. P. Christensen, nedskrevet af L. P. Chr., 17. 10. 1936, 22. 5. 1937, 23. 5. 1937 og 12.6.1937. Desuden KFlA 7. y. 2. u., L. Larsen til Bent Falkenstjerne/Udenrigsministeriet, 9.6.1937, og Erinnerungen, s. 284.

34. Sydslesvig gennem Tiderne I, s. 557.

35. DCB, W. Sievers til Stellvertreter des Führers, 11. 2. 1936. 
36. Fremgår af det $\mathrm{i}$ note 37 omtalte dokument, og af DCB, M. Bormann til Oberstes Parteigericht, 25. 5. 1936.

37. DCB, Lohse til Stellvertreter des Führers, 6. 4. 1936.

38. Samme.

39. DCB, omtales kort $i$ den overste partidomstols kendelse af 3.7.36. Akter herom findes i Bundesarchiv, NS 25/402 fol. 61ff., NS 25/405 fol. 68ff. og NS 25/416 fol. 141.

40. DCB, cit. efter den øverste partidomstols kendelse, 3.7.36.

41. DCB, omtales $\mathrm{i}$ den overste partidomstols kendelse.

42. Samme.

43. Hejmdal 14.5.1935, Grænsevagten 1935, s. 176-177.

44. DCB, se note 40 .

45. Se note 40 .

46. Se note 40.

47. Se note 40. Sievers bekræfter selv dette sit syn på Hans i Erinnerungen, s. 195.

48. Se note 40.

49. Se note 40. Desuden Erinnerungen, s. 283-84, hyor Lohses brev er aftrykt.

50. Erinnerungen, s. $284 \mathrm{ff}$. De omtalte breve gengivet: Sievers til Lohse, 9.11.35, på s. 284, Lohse til Sievers, 12. 11. 35, på s. 286, og Sievers til Lohse, 18. 11. 35, på s. 294-96.

51. Se note 40 .

51. $\$ 6$ lyder: Zur Vereinfachung der Verwaltung können Beamte in den Ruhestand versetzt werden, auch wenn sie noch nicht dienstunfähig sind. Wenn Beamte aus diesem Grunde in den Ruhestand versetzt werden, so dirfen ihre Stellen nicht mehr besetzt werden.\& Reichsgesetzblatt 1933, I. no. 34.

52. Jvf. Tägil, s. 63-64.

53. Samme s. 70-71.

54. Samme s. $71-72$.

55. Samme s. 72 og 75. Lenzing, s. 96-97.

56. Erinnerungen, s. 288-89.

57. DCB, Sievers til Stellvertreter des Führers, 11. 2. 1936.

58. DCB, Gaurichter Luitt/Gaugericht Schleswig-Holstein til Oberstes Parteigericht, 15. 5.1936.

59. DCB, M. Bormann til Oberstes Parteigericht, 25. 5. 1936.

60. DCB, W. Sievers til Oberstes Parteigericht, 13.6.1936.

61. DCB, Eröffnungsbeschluß, 17.6.1936.

62. Samme.

63. DCB, Nachtrag zum Eröffnungsbeschluß des Obersten Parteigerichts vom 17.6.1936, 26.6. 1936 .

64. DCB, domsudskrift m. Begründung, 3.7.1936. og Stellvertreter des Führers til W. Sievers, ?.8.1936.

65. DCB, Sievers til Oberstres Parteigericht, 4. 3. 1937.

66. Samme.

67. DCB, domsudskrift $\mathrm{m}$. Begründung, 2.7.37.

68. Jvf. DCB, M. Bormann til Oberstes Parteigericht, 25. 5. 1936.

69. Jvf. DCB, Chef der Sicherheitspolizei und des SD til Staatssekretär Stuckart/ Reichsministerium des Innern, 17.4. 1944.

70. Samme.

71. DCB, Dr. Sievers til SS/Sturm 11/15, Brandenburg, 21. 5. 1938, og H. Himmler til W. Sievers, 13.10.1938. 
72. DCB, Oberstes Parteigericht/dr. Volkmann til Sievers, 6.9.1938.

73. Jvf. DCB, Dr. Sievers til Reichsamtsleiter Jobst/München, 25.3.41.

74. Se note 73.

75. Se note 69 .

76. Håndskreven tilføjelse på det i note 69 omtalte dokument.

77. Jvf. Dr. Neesse'Partei-Kanzlei, München til Min.Rat Dr. Hoffmann/Reichsministerium des Innern, 9.6.1944.

78. Gedächtnisschrift, s. 12-13.

79. Erinnerungen, s. 308.

80. Gedächtnisschrift, s. $13 \mathrm{ff}$. 